\title{
Congenital pulmonary vein stenosis and bronchopulmonary vascular malformation
}

\author{
Estenosis congénita de venas pulmonares y malformación vascular broncopulmonar \\ Jesús De Rubens-Figueroa ${ }^{*}$, José J. Bobadilla-Chávez², and Sara A. Solórzano-Morales ${ }^{3}$ \\ ${ }^{1}$ Echocardiography Laboratory; ${ }^{2}$ Cardiology Department; ${ }^{3}$ Radiology Department. Instituto Nacional de Pediatría, Mexico City, Mexico
}

\begin{abstract}
The objective is demonstrate the diagnostic process and evolution of a patient with a diagnosis of congenital pulmonary vein stenosis and broncho-pulmonary vascular malformation. One year old female patient with repeated bronchopneumonia, acrocyanosis, split S2, cardiomegaly, pulmonary hypertension, with a clinical diagnosis of atrial septal defect. The echocardiogram demonstrated left sided vein pulmonary stenosis. The cardiac catheterization demonstrated arterial-venous fistulas apical on the right lung. Magnetic Resonance image and angiography showed an aberrant arterial vessel parallel to the abdominal aorta which flow the right pulmonary lobe. The cardiac tomography angiography reported confluence of right-sided pulmonary veins. A lobectomy is performed. Patient died in post-operative due to massive pulmonary hemorrhaging. This is the first patient mentioned in written literature with pulmonary vein stenosis associated with pulmonary sequestration, with normal venous connection. Echocardiography represents the specific standard study ideal for initial diagnostic for patients with pulmonary vein stenosis.
\end{abstract}

Key words: Pulmonary vein stenosis. Congenital heart disease. Pulmonary heart disease. Pulmonary sequestration.

\section{Resumen}

El objetivo es mostrar el diagnóstico y la evolución de una paciente con estenosis de venas pulmonares y secuestro pulmonar. Se trata de una niña de 1 año de edad, con bronconeumonías de repetición, acrocianosis, $2 R$ intenso, cardiomegalia, hipertensión venocapilar pulmonar, con diagnóstico clínico de comunicación interauricular. El ecocardiograma mostró estenosis de venas pulmonares izquierdas. El cateterismo cardiaco detectó fístulas arteriovenosas en la región apical del pulmón derecho. La imagen de resonancia magnética y la angiografía mostraron un vaso arterial aberrante paralelo a la aorta abdominal y con flujo dirigido al lóbulo pulmonar derecho. La angiotomografía reportó confluencia de las venas pulmonares del lado derecho. Se realizó lobectomía derecha. La paciente falleció en el posoperatorio debido a una hemorragia masiva pulmonar. Esta paciente es la primera descrita en la literatura con estenosis de venas pulmonares congénita asociada a secuestro pulmonar. La ecocardiografía es el estudio diagnóstico ideal inicial en los pacientes con estenosis congénita de venas pulmonares.

Palabras clave: Estenosis de venas pulmonares. Cardiopatía congénita. Enfermedad cardiaca pulmonar. Secuestro pulmonar.

\section{Correspondence:}

*Jesús De Rubens-Figueroa

E-mail: derubens@hotmail.com
Available online: $20-10-2021$ Arch Cardiol Mex (Eng). 2021;91(3):321-326 www.archivoscardiologia.com 2604-7063 / @ 2020 Instituto Nacional de Cardiología Ignacio Chávez. Published by Permanyer. This is an open access article under the CC BY-NC-ND license (http://creativecommons.org/licenses/by-nc-nd/4.0/). 


\section{Introduction}

Pulmonary vein stenosis has a population incidence of $0.03 \%{ }^{1}$, and can be congenital or acquired (secondary to radiofrequency ablation procedures, abnormal pulmonary veins surgery and states after Fontan, Mustard or Senning surgical procedures). One or more pulmonary veins can be involved, and it can occur isolated or associated with a heart disease ${ }^{2-5}$.

Congenital pulmonary vein stenosis (CPVS) is a rare cardiovascular disease, which is difficult to diagnose and often has a high mortality. Usual findings include stenosis of the junction between the vein and the left atrium, or its association with pulmonary veins diffuse hypoplasia, generally associated with some cardiac lesions ${ }^{6}$.

The first publication on the subject appeared in 1951, reporting about an 8-year-old boy who died as a result of complications of the disease ${ }^{7}$.

To the best of our knowledge, there is no other publication about a patient with CPVS without anomalous pulmonary venous return and pulmonary sequestration, which is why we present our experience in a patient with this pathology.

\section{Clinical case}

Girl born at 30 weeks of gestational age weighing $1400 \mathrm{~g}$, with crying-associated cyanosis since birth, failure to feeding and that had experienced recurrent bronchopneumonia.

At one year of age, physical examination revealed weight of $6,900 \mathrm{~g}$, length of $77 \mathrm{~cm}$, heart rate of 148 beats per minute, respiratory rate of 70 breaths per minute and blood pressure of $87 / 53 \mathrm{mmHg}$. She presented with crying-related acrocyanosis. Oxygen saturation was $83 \%$ breathing ambient air and $85 \%$ breathing oxygen. Nasal flutter, anteroposterior thoracic deformity, without murmurs, split $2 S$, palpable, normal pulses.

Chest X-ray showed cardiomegaly with cardiothoracic index of 0.64 and pulmonary hilar congestion and Kerley B-lines.

The electrocardiogram showed a heart rate of 140 beats per minute, QRS axis at $150^{\circ}$, negative ST-segment in right leads and right cavities enlargement.

At that moment, atrial septal defect and pulmonary arterial hypertension was diagnosed, with anomalous pulmonary venous return to be ruled out. Initial treatment consisted of captopril, furosemide and spironolactone.

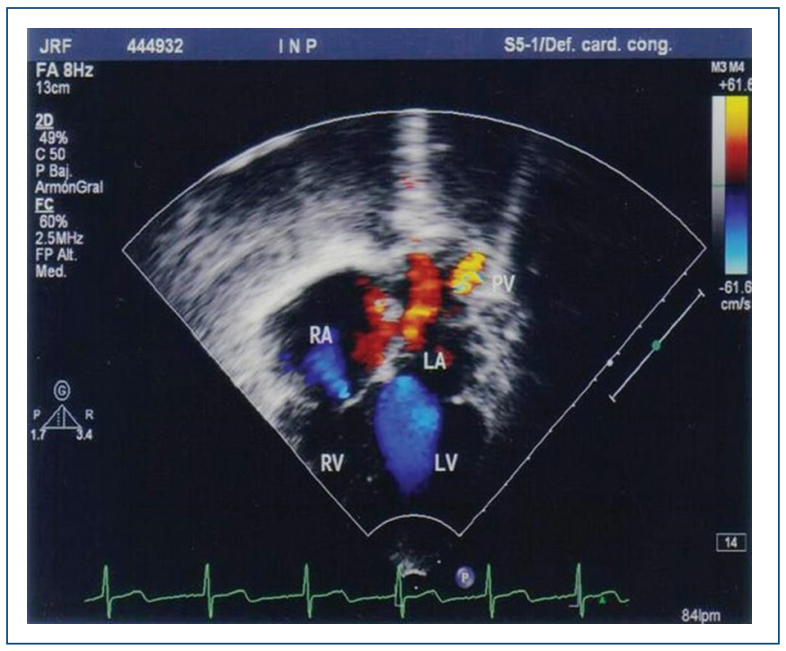

Figure 1. Two-dimensional color echocardiogram, in which left pulmonary vein color turbulence and right cavities enlargement is observed. LA: left atrium; LV: left ventricle; RA: right atrium; RV: right ventricle; PV: pulmonary vein.

Echocardiogram showed a 10-mm atrial septal defect of the venous sinus type with mixed shunt, pulmonary arterial hypertension of $68 \mathrm{mmHg}$ and left pulmonary veins stenosis (by presentation, the most common) ${ }^{5}$, demonstrated by color echo with turbulence and 25-mmHg maximum gradient (Fig. 1).

Cardiac catheterization (which is the standard diagnostic approach $)^{5}$ showed the atrial septal defect, all four pulmonary veins connected to the left atrium, left pulmonary veins stenosis and right pulmonary fistulae, with blood pressure of $100 / 46 \mathrm{mmHg}$ with a mean of $64 \mathrm{mmHg}$ (Fig. 2). Pulmonary resistance was $7 \mathrm{WU}$, and systemic, $9.1 \mathrm{WU}$.

Both angiography of the great vessels and magnetic resonance showed the presence of an aberrant artery originating in the abdominal aorta, which irrigated the right lower lobe middle portion; pulmonary sequestration was considered.

Abdominal ultrasound showed an aberrant vessel originating in the abdominal aorta above the celiac trunk, and confirmed arteriovenous fistulae.

Computed tomography showed stenosis of both left pulmonary veins connected to the left atrium, both confluent of a single trunk with 1.9-mm-diameter stenosis, arteriovenous fistulae formation originating from an arterial vessel, abdominal aorta branches that crossed the diaphragm on the right side of the pulmonary basal portion and that were divided in two small branches that anastomosed to the venous vessel (Fig. 3). 


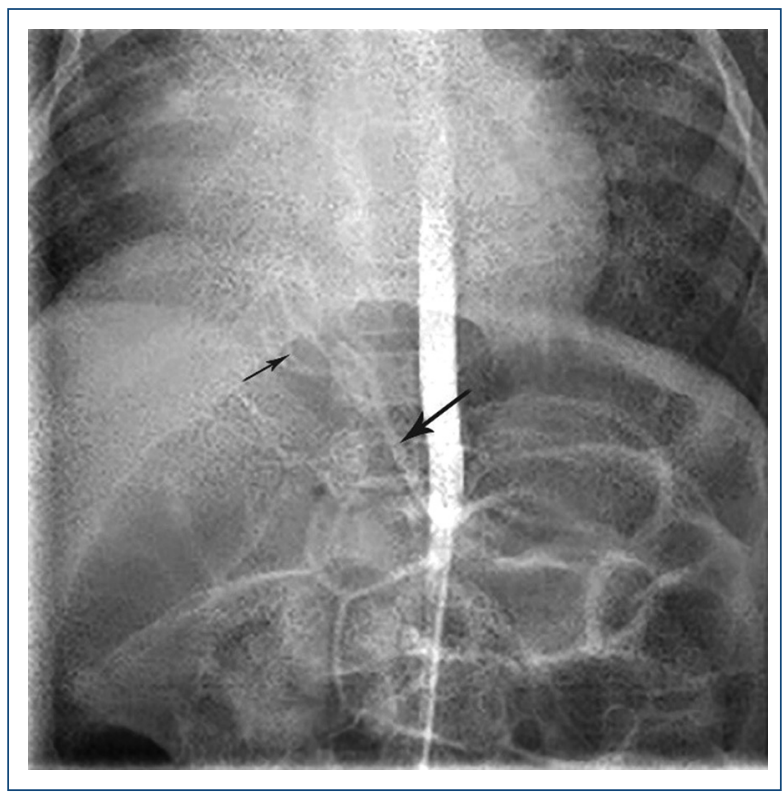

Figure 2. On cardiac catheterization, a right arterial fistula (thick arrow) emerging from the abdominal aorta towards the right pulmonary basal portion (sequestration) (fine arrow) is observed.

Since performing a pneumonectomy due to the pulmonary sequestration was decided (the possibility of placing a vascular occluder by interventional catheterization in order to decrease pulmonary sequestration flow was ruled out), a right posterolateral thoracotomy was performed, with the right lower lobe being found to be adhered to the mediastinal pleura; right pneumonectomy, enlargement of pulmonary venous stenosis with anomalous vessel ligation and sectioning were performed.

The patient was admitted to the intensive care unit, where she developed pleural bleeding $(170 \mathrm{~mL})$, respiratory acidosis and hypoglycemia, bleeding through the endotracheal cannula and left lung pleural effusion. The patient experienced respiratory failure for $8 \mathrm{~min}$ utes with severe bradycardia, with no response to treatment.

The autopsy revealed multiple congenital malformations: left pulmonary veins stenosis of and vascular arteriovenous malformation on right lung basal portion, which had been surgically corrected. A $10-\mathrm{mm}$ atrial septal defect, grade I-II pulmonary arterial hypertension secondary to pulmonary vascular disease, pulmonary hemosiderosis and right cavities hypertrophy were reported.

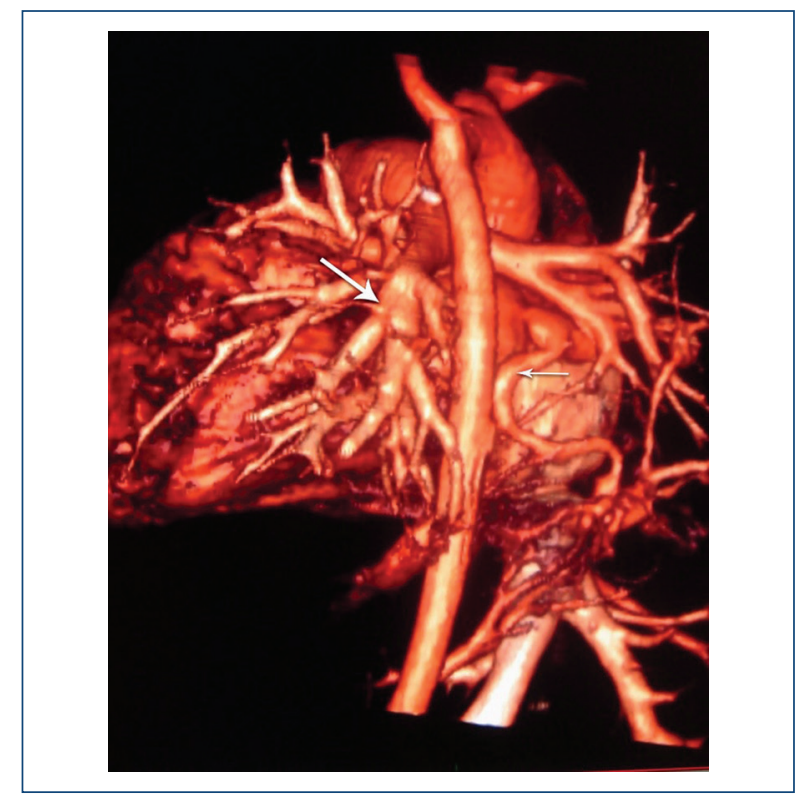

Figura 3. Tomografía computarizada en la que se observan la dilatación de las venas pulmonares izquierdas (flecha gruesa), que son confluentes, y el vaso aberrante (flecha fina).

The cause of death was massive postoperative pulmonary and mediastinal hemorrhage, right hemothorax, lung and cerebral edema with hypoxic-neuronal degeneration.

\section{Discussion}

CPVS is a problem around days 28 to 30 of gestational age, at the time embryonic separation of the pulmonary veins occurs ${ }^{8}$. Clinical manifestations of this pathology include diastolic or continuous murmur, right heart failure, low weight, respiratory distress, chronic pneumonia, hemoptysis, tachypnea, hypertension and pulmonary edema $a^{1,2,9-11}$.

The diagnosis was established with Doppler color echocardiography, which showed the CPVS and significant obstruction above $16 \mathrm{mmHg}$.

Flow rate should not exceed $1.5 \mathrm{~m} / \mathrm{s}$, and previous studies have shown, on echocardiograms, significant obstruction progression, right ventricular hypertrophy and pulmonary artery systolic pressure increase ${ }^{2,3}$.

Echocardiography is a specific standard study for initial diagnosis of this pathology, but has certain limitations: flow localization and alignment with Doppler at 


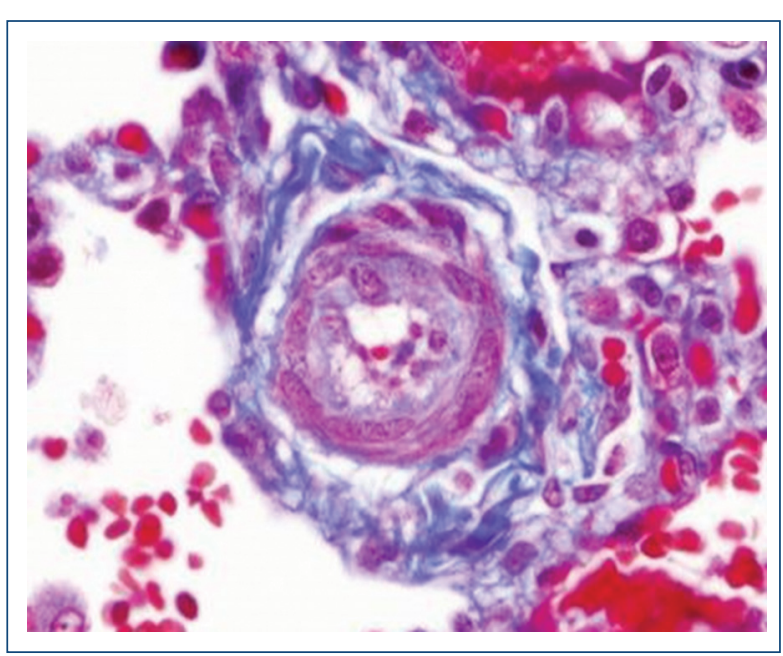

Figure 4. Pathology examination shows granulomatous inflammation and intimal focal fibrous proliferation (Dr. De León-Bojorge, Pathology Department).

$20^{\circ}$ or less (in patients with pulmonary atresia, blood flow could be lower) ${ }^{3,10}$.

Catheterization is the reference method for stenosis characteristics, and interventionism is useful in expert hands, but it is considered a palliative measure for cardiopulmonary transplantation ${ }^{5}$.

Computed tomography with three-dimensional reconstruction is the complementary imaging technique for characterizing the structures of the vascular system anatomy, as well as pulmonary veins ${ }^{5}$. If we understand that it is necessary to have data on the position of the pulmonary veins with respect to the atrium in order to determine the optimal surgical approach, imaging techniques (transesophageal echocardiography, computed tomography, magnetic resonance imaging and perfusion imaging) are essential for achieving refinement in final diagnosis ${ }^{12,13}$

CPVS is a pathological process that involves muscle thickening, neointimal myofibroblastic proliferation-tortuosity and extracellular matrix alteration, as well as platelet factor, vascular endothelial factor and fibroblast increase, with tyrosine kinase receptors activation and pulmonary arterial hypertension ${ }^{14,15}$.

Pathological examination showed granulomatous inflammation and intimal focal fibrous proliferation, which is described as an intra-parenchymal disease ${ }^{2,4,8}$ (Fig. 4). The mechanism of development is not well understood. Apparently, CPVS is a progressive lesion ${ }^{9,10,16}$.

CPVS is often associated with heart defects, such as atrial or ventricular septal defects, patent ductus arteriosus and single ventricles (30-80\%) $)^{1,3,4,6,7,17}$. In most cases, involvement is unilateral ${ }^{18,19}$. We found no cases associated with pulmonary sequestration.

The severity of the case will depend on the number of affected pulmonary veins, obstruction magnitude (30$46 \mathrm{~mm} / \mathrm{m}^{2}$ ) and the type of lesion (tubular, venous-arterial constriction or multiple hypoplastic lesions) $)^{2,20,21}$.

Predictors for re-intervention or even poor prognosis are late diagnosis, history of prematurity with respiratory distress, age under 6 months, weight lower than $3 \mathrm{~kg}$, pulmonary hypertension, right ventricular systolic pressure compromise or pulmonary vein bilateral involvement, and congenital heart disease with left-toright shunt ${ }^{2,11,14,19,22,23}$.

Our patient met several factors of poor prognosis: presence of pulmonary sequestration associated with pulmonary hypertension, atrial septal defect, history of prematurity with low weight and diagnosis at one year of age.

Patients with pulmonary veins stenosis or hypoplasia are difficult to manage $\mathrm{e}^{2,4,6,24,25}$. Some options are based on the use of beta-blockers, digoxin, anticoagulants, antiplatelet agents ${ }^{12}$, chemotherapy, supplementary oxygen, bosentan for the management of pulmonary hypertension ${ }^{5}$, balloon angioplasty or placement of stents (a challenge in children) with sirolimus (rapamycin) to prevent stenosis (not recommended when stenoses are located in venous ostia) ${ }^{18.26}$. Some authors consider surgery to be better than catheterization due to previous experiences of restenosis with catheterization ${ }^{16}$. Globally, experience with percutaneous intervention in children is limited ${ }^{12}$. Experience is required for the different surgical techniques: endovenectomy or venoplasty with pericardium or saphenous vein patches use, or marsupialization with pericardium, patch repair (classic technique) or without pericardial suture (current technique) $)^{1,4,6,12,25-28}$. We still lack experience for considering some of these techniques. Many of these procedures are palliative until heart-lung transplantation final treatment ${ }^{16}$.

In all these patients, there is a high incidence of restenosis $(50 \%)$, due to high neointimal proliferation 4 to 8 weeks after treatment ${ }^{1,2,8,9,17,28}$, which offers the possibility of a second intervention before 6 months, with reoperation rates of $40 \%$ and mortality of $30 \%^{29}$. This makes for the treatment of this pathology to be difficult and have a poor prognosis $8,9,21$.

A scale has been published for post-surgical prognosis with regard to risk of restenosis and 
reoperation, which takes into account pulmonary veins obstruction gradient, whether disease is unilateral or bilateral, lesion diffuse or focal appearance (most severe is atresia or occlusion) and whether the surgical technique is carried out with or without suture $^{29}$.

As for prognosis, 2-year survival in preterm infants has been reported to be $43 \%$, mortality in children younger than 1 year is around $65 \%$, and in those older than that age, it is $17 \%{ }^{16}$.

Global mortality 7 months after diagnosis by heart failure is $44 \% \%^{5}$, and at 3 years, it is $49 \%{ }^{23}$. Five-year survival in Boston and Toronto groups was $58 \%$ and $64 \%$, respectively ${ }^{22}$. With pulmonary bronchodysplasia and pulmonary arterial hypertension, surgery is highly risky, and previous interventional catheterization may be required ${ }^{16}$. Our experience in a series of patients it is quite limited.

Since the first CPVS corrective surgery in 1971, prognosis so far remains poor.

Pneumonectomy is indicated in cases with hemoptysis. Transplantation is another option, but with possible known complications, such as immunosuppression, neoplasms and obliterative bronchitis ${ }^{1,24}$.

In our patient, with an atrial septal defect diagnosis, there was clinical suspicion of left heart obstruction based on data consistent with pulmonary venocapillary hypertension observed on chest X-ray. An echocardiogram supported initial diagnosis.

We consider CPVS surgical correction with simultaneous pneumonectomy to be appropriate, although, unfortunately, the patient died due to a hemorrhage at the incision site during the immediate postoperative period.

\section{Conclusions}

Pulmonary vein stenosis should be ruled out in any premature infant with pulmonary hypertension with or without congenital heart disease, and an echocardiogram in expert hands should be carried out to confirm the diagnosis.

Always, in the presence of suspicion of venocapillary pulmonary hypertension, pulmonary veins lumen should be assessed with color echocardiography and Doppler.

Treatment of pulmonary vein stenosis is one of the biggest challenges among cardiovascular diseases. Interinstitutional experience is required.

\section{Funding}

None.

\section{Conflicts of interest}

We declare that there are no conflicts of interest.

\section{Ethical disclosures}

Protection of human and animal subjects. The authors declare that no experiments have been performed on humans or animals for this investigation.

Confidentiality of data. The authors declare that they have followed the protocols of their work center on the publication of patient data.

Right to privacy and informed consent. The authors declare that no patient data appear in this article.

\section{References}

1. Holt $\mathrm{BD}$, Moller HJ, Larson S, Johnson CM. Primary pulmonary vein stenosis. Am J Cardiol. 2007;99:568-72.

2. Latson AL, Prieto LR. Congenital and acquired pulmonary vein stenosis. Circulation. 2007;115:103-8.

3. Vick III WG, Murphy JD, Ludomirsky A, Morrow WR, Morriss JM, Danford $A D$, et al. Pulmonary venous systemic ventricular inflow obstruction in patients with congenital heart disease: detection by combined two-dimensional and Doppler echocardiography. J Am Coll Cardiol. 1987;9:580-7.

4. Van Son, AJ, Danielson KG, Puga JF, Edwards DW, Driscoll JD. Repair of congenital and acquired pulmonary vein stenosis. Ann Thorac Surg. 1995;60:144-50.

5. Laux D, Rocchisani MA, Boudjemline Y, Gouton M, Bonnet D, Ovaert C. Pulmonary hypertension in the preterm infant with chronic lung disease can be caused by pulmonary bien stenosis: a must-know entity. Pediatr Cardiol. 2016;37:313-21.

6. Driscoll JD, Hesslein SP, Mullins E CH. Congenital stenosis of individual pulmonary veins: clinical spectrum and unsuccessful treatment by transvenous balloon dilation. Am J Cardiol. 1982;49:1767-72.

7. Reye D. Congenital stenosis of the pulmonary veins in their extrapulmonary course. Med J Aust. 1951;1:801-2.

8. Sadr MI, Tan EP, Kieran WM, Jenkins JK. Mechanism of pulmonary vein stenosis in infants with normally connected veins. Am J Cardiol. 2000;86:577-9.

9. Bini MR, Cleveland CD, Ceballos R, Bargeron ML, Pacifico DA, Kirklin WJ. Congenital pulmonary vein stenosis. Am J Cardiol. 1984;54:369-75.

10. Smallhorn FJ, Pauperio H, Benson L, Freedom MR, Rowe DR. Pulsed Doppler assessment of pulmonary vein obstruction. Am Heart J. 1985;110:483-6.

11. Alsoufi B. Cracking the mystery of pulmonary vein stenosis. Semin Thorac Cardiovasc Surg. 2019;31:274-6.

12. Pazos LP, García RC, Guitián G, Paredes GE, Álvarez MA, Rodríguez AM, et al. Pulmonary vein stenosis: etiology, diagnosis and management. World J Cardiol. 2016;8:81-8.

13. Hong $\mathrm{H}$. Commentary: Management outcomes of primary pulmonary vein stenosis: what we know now and what we can expect in the future. J Thorac Cardiovasc Surg. 2020;159:1039.

14. Tsang TV, Tran KP. Pulmonary vein stenosis: challenges ahead. J Thorac Cardiovasc Surg. 2015;150:776.

15. Pogoriler JE, Kulik TJ, Casey AM, Baird CW, Mullen MP, Jenkins KJ, et al. Lung pathology in pediatric pulmonary vein stenosis. Pediatr Dev Pathol 2016;19:219-29.

16. Bonello B, Trivedi RK, Fraisse A. Multiple and aggressive pulmonary vein transcatheter interventions as bridge to transplantation in primary diffuse pulmonary vein stenosis. Cathet Cardiovasc Interv. 2015;86:e190-3.

17. Park CS, Neches HW, Lenox CC, Zuberbuhler RJ, Siewers DR, Bahnson TH. Diagnosis and surgical treatment of bilateral pulmonary vein stenosis. J Thorac Cardiovasc Surg. 1974;67:755-61.

18. Callahan R, Esch J, Wang G, Ireland MCH, Gauvreau K, Jenkins K. Systemic sirolimus to prevent in stent stenosis in pediatric pulmonary 
Arch Cardiol Mex (Eng). 2021;91(3)

vein stenosis. Pediatr Cardiol. 2020;41:282-9.

19. Rosenblum MJ, Altin FHK, Gillespie S, Heaton BH, Kanter A, Sinha R et al. Management outcomes of primary pulmonary vein stenosis. J Thorac Cardiovasc Surg. 2020;159:1029-36.

20. Breinholt PJ, Hawkins AJ, Minich LA, Tani LY, Orsmond SG, Ritter S, et al. Pulmonary vein stenosis with normal connection: associate cardiac abnormalities and variable outcome. Ann Thorac Surg. 1999;68:164-8.

21. Seale AN, Daubeney PEF, Magee AG, Rigby ML. Pulmonary vein stenosis: initial experience with cutting balloon angioplasty. Heart 2006;92:815-20.

22. De Campli MW. Pulmonary vein stenosis: plea for a multi-institutional registry. J Thorac Cardiovasc Surg. 2016;151:667-8.

23. Seale AN, Webber SA, Uemura H, Partridge J, Roughton M, Ho SY. Pulmonary vein stenosis: the UK, Ireland and Sweden collaborative study. Heart. 2009;95:1944-9.
24. Mendeloff NE, Spray LTH, Huddleston BCH, Bridges DN, Canter BCH, Mallory BG. Lung transplantation for congenital pulmonary vein stenosis. Ann Thorac Surg. 1995;60:903-7.

25. Devaney JE, Chang CA, Ohye GR, Bove LE. Management of congenital and acquired pulmonary vein stenosis. Ann Thorac Surg. 2006;81:992-6.

26. Ungerleider MR, Johnston AT, O'Laughlin PM, Jaggers JJ, Gaskin RP. Intraoperative stents to rehabilitate severely stenotic pulmonary vessels. Ann Thorac Surg. 2001;71:476-81.

27. Kirk RK, Kirshbom MP, Kogon EB. Surgical repair of pulmonary venous stenosis: a word of caution. Ann Thorac Surg. 2014;98:1687-91.

28. Victor S, Nayak MV. Deringing procedure for congenital pulmonary vein stenosis. Tex Heart Inst J. 1995;22:166-9.

29. Kalfa D, Belli E, Bacha E, Lambert V, Duccio di C, Kostolny M, et al. Primary pulmonary vein stenosis: outcomes, risk factors and severity score in a multicentric study. Ann Thorac Surg. 2017;104:182-9. 